\title{
ORGANIZATIONAL CULTURE AND CONCEPT OF KNOWLEDGE MANAGEMENT IN MODERN COMPANIES
}

\author{
Nikcevic Gordana ${ }^{1}$
}

\begin{abstract}
Modern development of economy and society, characterized by the development of technology and techniques, is based on knowledge management. Modern companies consider defining, promotion, evaluation, and knowledge management as their key challenges. Organizational culture is a key component which should ensure the effective creation and use of knowledge within the company. In this context, creation of organizational culture which will recognize the importance of collective knowledge represents one of prerequisites for the effective knowledge management.
\end{abstract}

Key words: organizational culture / knowledge / knowledgemanagement/company

\section{INTRODUCTORY CONSIDERATIONS}

In modern society characterized by uncertainty and changes, knowledge is the only true source of competitive advantage. In conditions when telecommunication systems and the Internet are developing and competition is growing, the rules of modern companies' operations are significantly changing. Only companies that continuously monitor new trends, invest in their own development and acquire new knowledge achieve competitive advantage.

In market game a large number of companies do not achieve expected results, i.e. they do not use their competitive advantages. One possible reason for this situation is inadequate use of existing knowledge in the company. Therefore, the company has a task to attract, use, renew and increase knowledge within the company. Namely, knowledge management enables managers at various levels of management to solve problems successfully using their own knowledge and all other knowledge within the company. However, it is not enough to determine the concept of knowledge

1 PhD candidate at the Faculty of economics in Podgorica, Montenegro, e-mail:gogan@t-com.me 
management, but it is necessary to create conditions for its implementation. Having in mind that employees are the main source of knowledge in the company, the essential problem is how to motivate employees to share their knowledge with others and use it. Since most of the knowledge lies in the heads of people who work in the company, and organizational culture affects ways of thinking and behavior of employees, it is necessary to consider the importance of organizational culture in relation to the effectiveness of knowledge management in companies.

The aim of this paper is to show the connection between organizational culture and the concept of knowledge in the company. Through presentation of impact of different elements of organizational culture and their effects on implementation of knowledge, relevant factors necessary for the success of this process will be identified. This way, the most important problems that may arise during implementation of knowledge will also be identified.

\section{CONCEPTUAL DEFINITION OF ORGANIZATIONAL CULTURE}

A single definition of organizational culture does not exist. Most definitions emphasize values and norms, that is, its cognitive component. Organizational culture is "a set of assumptions, values, norms and attitudes that members of a company have developed and adopted through shared experience, which are manifested through symbols that guide their thinking and behavior"(Janićijević, 2013:35). From the above definitions three important components that are needed for better understanding of organizational culture arise. First, organizational culture consists of collective cognitive structures such as assumptions, values, norms and attitudes, but also of symbols that materialize and manifest its cognitive content. Second, organizational culture is the result of shared experiences of organization members in solving problems they are faced with when solving problems of external adaptation to the environment and internal integration of a collective. Third, collective cognitive structures that comprise organizational culture content provide a framework and guidelines for members of the company in interpreting reality and the world around them. Culture helps members of the company to determine the meaning of concepts, things and events both within the company and outside of it and act accordingly.

As a result of previous research in this area, it is important to emphasize that organizational culture has got its legality both in organizational theory and organizational research. Moreover, the culture has become an accepted way of interpreting and monitoring the life of every company. Organizational culture affects all aspects of business. However, so far, far more attention has been paid to 
positive rather than negative impacts, better to say negative impacts on the company have been generally ignored. The reason is to represent organizational culture in a positive light which can also be counterproductive. Namely, it is necessary to master organizational culture in order to achieve through it positive and avoid negative impacts on company's operations.

Culture is a very important part of success of the concept of knowledge management in the company. Change of culture includes initiative, recognition and advancement, but the most important is the existence of a climate of trust in which knowledge sharing is encouraged. Determining organizational culture as an important factor that determines effectiveness of knowledge management in the company, the author will emphasize the fact that only the culture whose content comprise orientation towards people, openness, learning, knowledge sharing, teamwork, willingness to take risks, willingness to change, may have a positive impact on knowledge management.

\section{KNOWLEDGE, TYPES OF KNOWLEDGE AND KNOWLEDGE MANAGEMENT}

There is no universal definition of knowledge that would encompass all aspects of it. Knowledge represents our evaluation and evaluation that is based on meaningfully organized set of information which we experience, obtain through communication and reasoning (Zack, 1999a: 45-58).

In the attempt to systematize knowledge different classifications of knowledge arose. From the perspective of operations and functioning of the company the most important are those classifications that contribute to effective knowledge management. One of those classifications encompasses five types of knowledge:

- declarative - knowledge about,

- procedural - know-how,

- causal - know - why,

- conditional - know - when, and

- relational - know - with (Zack, 1999b). 
Knowledge can be divided into individual and organizational knowledge. Individual knowledge includes knowledge of an individual, i.e. human capital that enters in and out of the company on a daily basis. It includes: experience, knowledge, ideas, creativity, readiness for changes, etc. Organizational knowledge is knowledge that is owned by certain organizational unit. Organizational knowledge encompasses: patents, processes, projects, information, technology, licenses and the like. If the company is seen as a set of individuals we come to the conclusion that organizational knowledge represents the sum of all individuals' knowledge. However, organizational knowledge is more than that. It also includes a synergic component which implies that if individuals cooperate, in addition to their own knowledge, they also create additional knowledge that is the result of cognitive process and refers to improvement of knowledge. Specifically, individuals bring certain knowledge with them; knowledge acquired in educational process, and gives it, through organizational knowledge, to "organizational knowledge". Thus the organizational knowledge increases. Likewise, individuals, using knowledge and expertise from other sources, also increase their own knowledge, thereby increasing, through organizational knowledge "knowledge of organization" even more. Thus we get a Snowball effect - as it rolls it gets bigger. So, each individual is a key factor in spreading and increasing of knowledge, so that all activities in the company should be focused on continuous improvement of company's employees. Accordingly, employees are not regarded as labor or expense, but as producers of income for the company. Bearing in mind that new knowledge represents a base for other new skills, modern companies have a task to constantly innovate programs of employees training, discover hidden knowledge of its employees, accept new knowledge deepening analysis of work processes in the company, motivate workers to adopt new knowledge, etc. (Orlić, 2008: 12).

From the perspective of knowledge management strategies, knowledge may be divided into explicit and implicit knowledge. Explicit knowledge is objective, open, and palpable. It is expressed in formal language in the form of data, specifications, formulas, manuals, etc. It does not depend on the context in which it was created and can hardly be transformed and transmitted. Implicit knowledge is subjective, hidden and impalpable. It is knowledge that is deeply personalized and can hardly be formalized. It depends on the context in which it was created and can hardly be transformed and transmitted. That is because implicit knowledge contains intuition, ideas and knowledge that we cannot express, but we can apply it. Implicit knowledge is made of technical and cognitive elements. Technical elements of implicit knowledge include informal trade skills and know-how. Cognitive elements are individual for each person. With their help, individuals understand the world. 
A skill that makes a technical part of implicit knowledge also arises from them. Articulation of implicit knowledge is an essential way of creating new knowledge in the company (Janićijević, 2008:386).

In order to manage knowledge efficiently it is necessary to identify all sources of knowledge available to a company. In general, two sources of knowledge can be identified, such as: internal and external sources. Internal sources of knowledge are in people's "minds" and express themselves through behavior of employees, procedures, software and equipment. They are found in different documents and databases of companies. External sources of knowledge of general interest include publications, universities, government agencies, etc. (Zack, 1999a). Regarding a company's orientation with respect to sources of knowledge there are three possible options. The first option refers to companies that only use knowledge from their own sources. However, the orientation of the company mainly to internal sources can adversely affect the competitive position of the company. The second option that relates to those companies which are oriented only on external sources of knowledge causes instability in company's operations because external sources of knowledge are relatively inexpensive and widely available. The third option occurs by using knowledge from internal and external sources. This option is considered to be the best because it represents a combination which eliminates orientation shortcomings only to internal or only to external sources of knowledge.

Stemming from information as a primary factor in the constitution of knowledge, knowledge management can be defined as the systematic and organizationally specified process of acquiring, organizing and communicating knowledge of employees so that other employees may make use of it to be more effective and productive in their work (Alavi, Kayworthand and Leidner, 2005) Knowledge management encompasses three main activities of knowledge:

-Knowledgegeneration - includes all activities, which bring to light knowledge that is "new" to the individual, to the group, and to the organization;

- Knowledge transfer - movement of knowledge from one location to another and its absorption;

- Knowledge retention - all activities taken for the retention of acquired knowledge within the company.

One of the prerequisites for efficient knowledge management is to create organizational culture that will help the process of knowledge implementation and which will activate that knowledge so that it creates additional values for the company. 


\section{INTERDEPENDENCE BETWEEN ORGANIZATIONAL CULTURE AND KNOWLEDGE MANAGEMENT}

The essence of the concept of organizational culture within the company lies in the fact that every company shapes its value systems, beliefs and norms, which will be sufficiently attractive and acceptable to all the people in the company. By accepting a certain value system employees strongly link themselves with the company and integrate themselves into an entity. In fact, the presence of mental models that are specific creates a space for the existence of such an environment that will favor the development of knowledge in the company, i.e. creating a kind of organizational model in which knowledge will have a primary role (Pržulj, 2000:14).

The concept of knowledge management assumes that knowledge is the only reliable source of permanent competitive advantage. However, in order to create and maintain a competitive advantage, a company must be able to generate and apply new knowledge. To be able to spread knowledge, share it and let it flow freely within the company-it is essential that employees feel uninhibited, without fear that their division of knowledge would lead them to a worse business position. Employees need to understand exchange of knowledge as a possibility for their personal development and progress, as well as progress of the entire company. In this sense, it is necessary to create such an organizational culture that is characterized by: a high level of autonomy for individuals' respect for skills, knowledge and talents, low-level office policy of minimal but effective administration, encouraging, encouraging a shared stake in the outcomes, giving recognition and making employees feel valued, high levels of involvement if employees in decision-making, building variety into jobs, cooperation rather than competition, etc. In such an environment, employees will feel free to express their ideas, feelings and learning together and organizational culture will support the implementation of knowledge and enable development of knowledge sharing culture. Organizational culture positively affects and encourages knowledge management to the extent that the assumptions, values, norms and attitudes shared by employees are such as to support and encourage knowledge management. However, if the assumptions, values, norms and attitudes shared by the employees are such that they do not support and encourage knowledge management, these processes will encounter cultural barriers and will hardly be implemented as less efficient (Harman, Brelade, 2000).

Creation, sharing and implementation of knowledge in the company requires changes. One of the main obstacles to the adoption of new knowledge may be the existing knowledge. In order for employees to accept new knowledge in a company they have to leave their existing knowledge. Employees often resist changes. In 
addition to the fact that it is in nature of human character, they perceive changes as imposition, rather than enhancing their role in business. Organizational culture determines the willingness of employees to reconsider and leave the existing knowledge. In some cultures, assumptions and values are such that they encourage reexamination of existing knowledge and beliefs. In such cultures it is simple to leave the "old" knowledge and adopt a new one. However, there are cultures in which reexamination of the existing and adoption of new knowledge is "forbidden". Then it is very difficult for employees to change anything, even in case when they have an incentive to change and adopt new knowledge (Janićijević, 2013:335).

In addition to the above, it is very important that openness exists in internal communication which means that information in the company is shared with everyone. Therefore, everything within the company should be resolved in an honest and open discussion, avoiding conflict situations. It is also important that there is a systemic perspective, which means that every individual in the company, regardless of their position, analyses issues in the company from the aspect of the company as a whole, not its parts. Some authors think that a place for sharing knowledge must exist within a company, which is the key for successful implementation. There must be a place to acquire, organize and disseminate knowledge. It has to be well structured and appropriate for all employees (Greengard, 1998).

Unsuccessful managers' initiatives related to knowledge are in most cases the result of a culture that does not support the concept of knowledge. In that sense, awareness of the importance of knowledge and willingness to support its implementation is needed. Prerequisites for the creation of an atmosphere of knowledge sharing in the company are: determination of direction and exchange of opinion about the goals set, proper relationship towards employees as professionals and transparent structure that is based on development and teamwork. Employees should understand that sharing knowledge increases the quality of knowledge and, as such, represents a much greater benefit to the company than the possession of knowledge. Therefore, it is necessary to remove cultural barriers in order to establish the exchange of knowledge in the company (Vemić, 2007).

Based on the above, it can be concluded that there is a mutual dependence of organizational culture and knowledge management. In order for companies to adjust timely and adequately prepare themselves for successful performance in an unpredictable and dynamic business environment, they are turning more and more to knowledge as the only form that they can create them the ability to create and maintain competitive advantage. 


\section{ELEMENTS OF ORGANIZATIONAL CULTURE IMPORTANT FOR KNOWLEDGE MANAGEMENT}

Many studies have shown that of all the factors that affect knowledge management (strategy, structural factors, information technology, staff qualifications, clearly defined goals, reward system, etc.) organizational culture has the largest impact on knowledge management. It is very important for a company to recognize the importance of impact of certain elements of organizational culture that are important for knowledge management. In this way, a company will find the most optimal relationship between current organization and knowledge and conceive the right strategy for organizational culture transformation. The influence of the most important organizational culture elements on knowledge management is described below (Mertins, Heising and Vorbeck, 2001:1-57).

1. Organizational culture shapes assumptions about what knowledge is. In that context:

- Culture includes assumptions about what kind of knowledge is important. In this sense, the authors distinguish individual knowledge that can be a skill or an expertise, social knowledge that represents the knowledge of a group of people and structure knowledge that is represented in the company through policies and procedures;

- Culture, through its assumptions and values, defines what is important to know, i.e. which part of a company needs to be known (technical, economic, or social knowledge);

- Culture defines the boundary between the individual, group and organizational knowledge. Which kind of knowledge the individual will keep for himself /herself and which one he/she will share with others depends on the company's organizational culture, i.e. cultural assumptions and norms. People do not often want to share individual knowledge considering it a source of power within a company (Janicijevic, 2013:333).

Subcultures have a vital role in shaping organizational behavior. Subcultures contain specific types of beliefs, norms and practices presented through specific groups within a company. They differ from the overall organizational culture, as well as from other subcultures. The company, in addition to the dominant culture, may have several subcultures. However, the impact of organizational culture, meaning of subcultures and their conflicts differ in companies (Schein, 1996). 
Certain cultures will only value the "objective" knowledge that can be integrated into processes and systems, while others will favor the knowledge resulting from social interactions. This can create a conflict between sectors of the company because there are different systems of knowledge evaluation in different sectors of a company (marketing, financial, human resources). (De Long, 1997:113)

2. If culture is an intermediary between the individual and organizational level of knowledge, norms of possession of knowledge gain more importance. In this sense, culture should facilitate a process of knowledge sharing. Words of the CEO at Buckman Laboratories show how to transform the company norms which regulate relationships between individual levels of knowledge and a company.

"Those of you who have something intelligent to say now have a platform or forum in which to say it. If you are not willing to contribute or participate, then you should understand that many opportunities offered to you in the past will no longer be available" (De Long, 1997:115).

Organizational culture by its assumptions, values and norms determines what is individual and what organizational knowledge is. In this sense, it defines knowledge and competencies that are valuable to the company, shapes interactions and communication through which organizational knowledge is being created, shared and used. Organizational knowledge becomes relevant and makes sense only if it can be managed, i.e. if it is used in the company. Knowledge management has as a result changes in cognitive structures of employees and changes in their behavior. In order for knowledge to have positive consequences for the company it is needed that the change in employees' awareness leads to changes in their behavior. In this sense, organizational culture should create an environment in which individual knowledge is to be converted into organizational knowledge. Socialization is the first form of creation of organizational knowledge. Through a process of social interaction, implicit knowledge (which was previously discussed) is transmitted from one individual to another. (An example of this is transfer of knowledge from craftsman to apprentice, during their mutual work, where a craftsman does not explicitly transfer his knowledge to the apprentice, but the apprentice "absorbs" knowledge from the craftsman through social interaction process). Conversion of implicit into explicit knowledge is done through articulation process. In this way, individual knowledge, i.e. knowledge that it was only in the possession of individuals, turns into common good of the organization. It is not simple, because it is needed that 
one who possesses implicit knowledge has the ability and willingness to articulate it into explicit knowledge. Combination is a form of conversion of individual knowledge and creation of organizational knowledge in which elements of explicit knowledge are integrated into wholes that are more complex than their parts. After this process, knowledge is spread in the company; it is available to employees and may be used as such. However, the process of knowledge conversion has not been finished yet. Internalization is a form of knowledge conversion in which explicit knowledge through everyday use becomes an integral part of mental schemes of employees and managers, i.e. it is converted into implicit knowledge. It is important to emphasize that the process of knowledge internalization is not only done in the workplace, but through education and staff training. Through education and training, employees enrich their explicit knowledge, which as such articulate into implicit ones. Surely, new and enriched implicit knowledge is converted again into the explicit one by which the circle of knowledge conversion is closed. Using organizational knowledge is manifested in changed and improved behavior of employees in the company, i.e. their decisions and actions. As a result of these changes, companies will be able to respond to demands of the environment and improve their competitive advantages (Janićijević, 2008:386).

3. Through context of social interaction, organizational culture determines how knowledge will be used in certain situations. Companies that are not characterized by knowledge sharing behavior cannot provide for behavior where the experience of a group will be transferred to another one even if they have technological requirements created for doing so.

The impact of culture on interaction context can be seen through:

- Vertical interactions that are reflected in the eligibility of employees to freely express their opinions and discuss all issues. Culture which implies openness and freedom in communication on different levels positively affects knowledge management and vice versa.

- Horizontal interactions that are manifested through communication between individuals and groups. Through norms and practices, a culture determines cooperation level (a culture that supports collective responsibility is positive for knowledge management), and the extent to which employees will be free to seek solutions to problems in new knowledge, out of the existing one. 
- There are also specific kinds of behavior that a culture supports or does not support. If culture encourages employees to teach others and share knowledge it means that such a culture is good for knowledge management. Similarly, a culture that tolerates mistakes positively affects knowledge management (Janicijevic, 2013:334).

Namely, by establishing the context for interaction, organizational culture determines how knowledge will be used in a particular. Governing social interactions between individuals and groups comes down to shaping individuals' perceptions of their range of options acceptable to the firm. If, for example, a firm has no behavioral routines or expectations for capturing critical feedback from customers and converting it into product or service improvements, then no context exists to support the interactions needed to develop and apply new knowledge about the market. And, if in an organization where interdependent functions exist there is no expectation to share knowledge and collaborate, and where no routine practices exist to do so, then there's no context for interaction to support this sharing. In that case, a new electronic knowledge base or reengineered work process will improve the environment for knowledge sharing, but unless senior management addresses long-standing interaction patterns and beliefs shaped by different subcultures, the benefits of the knowledge strategy will be limited situation (De Long, 1997:20).

4. Organizational culture determines how the new organizational knowledge will be adopted and communicated. The dynamics of this process is quite complex and may represent an issue for the company.

In fact, if they want to survive competition with others, companies need to be able to adopt, validate and transfer new knowledge. Therefore, the question which often arises is: what are the characteristics that a culture should have for the effective integration of new knowledge. Some of them are the following ones:

- Knowledge from the external environment is expected to be the starting point, not the end, of innovation. External knowledge is regarded as the starting point, not as the end of the acquisition of problem-solving knowledge. Instead of simple, external absorption of knowledge, also the exploitation of external knowledge is carried out in an organization.

- An intense debate on key strategic issues with the use of external ii internal information has been encouraged. This norm stems from the values of openness, co-operation and autonomy.

- A high level of participation of employees is expected in adoption and discussion about knowledge related to importance of business outcomes. 
- Induction of assumptions underlying the previous success of a company has been supported. This norm stems from the valuation of openness to new experiences (Kolarić, 2009:9).

\section{PREJUDICES AND PRINCIPLES IN THE COURSE OF INTRODUCTION OF KNOWLEDGE CONCEPT IN ORGANIZATIONAL CULTURE}

Certain problems may often arise in the course of knowledge concept implementation, which makes its application difficult. Therefore, certain principles were established that facilitate implementation of knowledge within companies. Aggravated circumstances in application of knowledge in organizational culture are: (Wheatley, 2004)

- Organizations and people are treated like machines. This understanding particularly comes to the fore if companies as treated as separate parts. Companies are expected to achieve their goals automatically. People are also expected to do whatever they are told.

- Only material things are real. Errors usually occur due to attempt to attribute unobservable forms of knowledge to material forms.

- Only numbers are real. Only when something is quantified, i.e. expressed in figures, it is possible to describe it adequately.

- Only what you can express in measure or in figures can be managed with. If this is impossible, one should not pay attention to it.

- Observation of technology as a solution to all problems. In fact, insisting on technology creates additional problems, because it cannot be noticed that information expressed in figures are not able to describe the essence of the problem.

However, there are also principles whose application considerably facilitates implementation of knowledge concept.

- It is believed that man creates knowledge. In this sense, a human being cannot be regarded as a machine, but it is necessary to focus attention on him and his needs, i.e. organizational culture that supports people and their mutual relationships.

- Creating and sharing knowledge is in the nature of human activity. Organizational culture needs to motivate people to learn, create and share knowledge, to participate in decision-making, etc. 
- Each individual is a knowledge worker. If we assume that each individual creates knowledge, then the company should support each employee individually, because you never know who will find a solution to a problem needed for the company itself.

- Employees decide to share their knowledge. Problems within the company may occur because employees do not share their knowledge. Employees will share their knowledge when they have sense that they belong to the company, feel respect and trust, understand and evaluate goals of the company, believe in their leaders, etc.

- Problems that may arise when creating and implementing knowledge management cannot be solved solely by technology. None of technology solutions is a solution if it does not respect the human dimension.

- Creation of knowledge is a process that takes certain time. Namely, indication of knowledge, innovation or idea never arises in predetermined sequence, but suddenly in an unplanned process that requires time.

\section{POSSIBLE PROBLEMS IN IMPLEMENTING KNOWLEDGE}

During implementation of knowledge various problems may occur in the company such as:

- Problem of knowledge sharing. There are many reasons that prevent people to share their knowledge with employees in the company,

- Lack of adequate rewards for knowledge sharing,

- It is in human nature to believe that the knowledge people own increases their strength,

- Lack of adequate methods and means of collecting and classifying knowledge,

- Individuals do not share their knowledge, because they are not aware of what they actually know (Drummond, Saidel, 2004:291-299).

Some people believe that employees do not like to share knowledge for the following reasons:

- "People do not like to share their best ideas". They believe doing so dilutes their standing in the organization, and can impede their ability to get ahead. 
-"People don't like to use other people's ideas for fear it makes them look less knowledgeable, and that they're suddenly dependent on others to do their job".

- "People like to consider themselves experts and prefer not to collaborate with others" (Greengard, 1998).

For effective management it is necessary to develop organizational culture that will initiate and promote team work, trust and knowledge sharing among employees through its content (Davenport, Prusak, 2000:25). Also very important is daily encouragement and improvement of a large number of interactions among employees at all levels. Factors that through its impact on organizational culture hinder or impede the transfer of knowledge are: lack of confidence, a different cultures, lack of time and place for meetings, lack of absorptive capacity of a knowledge recipient, the belief that knowledge is the benefit of certain groups, etc.

One of the problems in the process of knowledge management is the issue of employees' motivation. The question is how to motivate employees to share their knowledge with others. In order for organizational culture to support and motivate employees in that sense, it should enable them the following: personal development, work environment where they can carry out their tasks, a possibility to get the job done so as to meet all standards, an adequate material rewards etc.

It is important for companies to find long-term ways to motivate their employees, in order to create, share and use knowledge. The company will not be able to support for a long-term employees' incentive and process of knowledge implementation, if it only offers motivation in the form of additional money. Therefore, it is necessary to combine the reward system, i.e. salaries, with non-financial rewards (development, responsibility, recognition). In this case, they will be motivated: to strengthen their moral commitment for the survival in the company; to increase their efforts; to exceed their goals.

The goal of knowledge management is to improve the process of knowledge documentation, collect and retain knowledge and enable access to existing knowledge. Also, if it is necessary, organizational culture should be changed, communication and co-operation among employees improved and individual development of each individual strengthened. In that sense, the aim is to convert implicit into explicit knowledge and to improve its exchange. To sum up, the purpose of knowledge management is to maximize the effectiveness of all organizational activities related to knowledge (Tisen, Andriesen and Lekan Depre, 2006:206212). 


\title{
CONCLUSION
}

Knowledge represents the most important capital of a company. In that sense, it is necessary to develop an efficient system of such capital, as it leads to significant savings, increased productivity, better quality of business performance and creating competitive advantage. If there is only knowledge in a company, but not an established knowledge management system, it will not be used effectively. Knowledge management enables companies to maximize long-term competitive advantages.

Organizational culture is an effective mechanism for coordination and control of knowledge. For efficient knowledge management it is required to have such an organizational culture that promotes knowledge as the most important source of competitive advantage and power. There is a need for knowledge not just because of knowledge, but knowledge that can be applied, that can create innovation and competitive advantage. Knowledge that has strategic importance for a company and that will increase its value is the important one.

In the context of knowledge management only the organizational culture that promotes a high level of autonomy for individuals, respect and reward knowledge, knowledge sharing, participation of employees in decision-making, co-operation and flexibility, may be of a great importance. At the same time, the mentioned positive characteristics of organizational culture represent guidelines for possible redefinition of the content of organizational culture in the context of achieving the effectiveness of knowledge management within a company.

\section{ORGANIZACIONA KULTURA I KONCEPT UPRAVLJANJA ZNANJEM U SAVREMENIM PREDUZEĆIMA}

\author{
Nikčević Gordana
}

Sažetak: Savremeni razvoj privrede i društva, koji karakteriše razvoj tehnike $i$ tehnologije, zasniva se na upravljanju znanjem. Ključni izazov savremenih preduzeća jeste definisanje, unapredivanje, vrednovanje i upravljanje znanjem. Organizaciona kultura je ključna komponenta koja treba da osigura efikasno stvaranje $i$ korišćenje znanja u preduzeću. U tom smislu, stvaranje organizacione kulturekoja će prepoznati znaćaj kolektivnogznanja predstavljajedan od preduslova za efikasno upravljanje znanjem.

Ključne reči: organizaciona kultura / znanje / upravljanje znanjem / preduzeće 


\section{LITERATURE}

1. Alavi, M., Kayworth, T.R. and Leidner, D.E. (2005), An empirical examination of the influence of organizational culture on knowledge management practices, Journal of Management Information Systems, Vol.22, No.3, pp.191-224.

2. Davenport, T. H., Prusak, L. (2000), Working Knowledge: How Organizations Manage What They Know, Boston, Harvard Business Shool Press.

3. De Long, D. (1997), Building the Knowledge - Based Organization: How Culture Drives Knowledge Behaviors, Boston, Center for business innovation.

4. Drummond, P., Saidel, G.B. (2004), CapturingIdeas, Creating Infromation and Liberating Knowledge, San Francisco, Leader to Leader Institute.

5. Greengard, S. (1998), Will your culture support KM?, Workforce, Vol. 77, No. 10, pp. 93-4.

6. Harman, C., Brelade S.(2000), Knowledge mangemnet and the Role of HR. Securing Competitive Advantage in the Knowledge Economy, London, Prentice Hall.

7. Janićijević, N.(2008), Organizaciono ponašanje, Beograd, Data Status.

8. Janićijević, N.(2013), Organizaciona kultura i menadžment, Beograd, Ekonomski fakultet.

9. Kolarić, B. (2009), Odnos organizacione kulture i menadžmenta znanja, Sremski Karlovci, Visoka škola strukovnih studija za menadžment i poslovne komunikacije.

10. Mertins, K., Heising, P. and Vorbeck, J.(2001) Knowledge Management Best Practices in Europe, Berlin, Springer - Verlag.

11. Orlić, R. (2003), Osnovna znanja kompanije, Beograd, Poslovna politika.

12. Pržulj, Ž. (2000), Kultura i preduzetništvo, Beograd, Zadužbina Andrejević.

13. Schein, E. H. (1996), Three cultures of management: The key to organizational learning, Sloan Management Review, Vol.38, No.1, pp.920.

14. Tisen, R., Andriesen, D. and Lekan Depre, F. (2006), Dividenda znanja, Novi Sad, Adižes.

15. Vemić, J.(2007), Employee training and development and learning organization, Economics and Organization, Vol. 4, No 2, pp. 209 - 216. 
16. Wheatley, M.J.(2004), The Real Work of Knowledge Management, Leading Organizational Learning, Lossey-Bass, San Francisco, Leader to Leader Institute.

17. Zack, M. (1999a), Developing a Knowledge Strategy, California Management Review, Vol. 41, No. 3, pp.125-145.

18. Zack, M. (999b), Managing Codified Knowledge, Sloan Management Review, Vol. 40, No. 4, pp. 45-58. 